\title{
DISBALANCE BETWEEN TAX ASSESSMENTS AND MARKET PRICES OF REAL ESTATE
}

\author{
D. Ushatova* \\ Department of Regional Development, Trakia University, Stara Zagora, Bulgaria
}

\begin{abstract}
The research aims to show some deficiencies in the legal framework including the formation and of property tax assessment and their deviation from the market values. Experimental results of price comparisons of market values in 1 BGN per 1 sq.m. are compared three groups of properties (apartment, house and plot) in selected settlements - district centers. Compare the prices of these properties advertised on a national real estate site and the average price of residential property, according to NSI data with the conditionally calculated value of a tax assessment for each type of property under review. Trends are established for the three-year period and general conclusions are established. Based on the results of the study, some key guidelines are proposed for the formulation of the tax assessment distribution, as well as a forecast / deficit-forecasting model that is formed in municipal budgets as a result of the disproportion between valuations and real prices.
\end{abstract}

Key words: rating norms, properties, municipalities, local taxes, properties, formula

\section{INTRODUCTION}

In the public space, the question of the cheap properties of some political figures was discussed very actively. Outside the focus of the debates remained the discussion of the main problems of the existence of such imbalances between the market prices and the prices at which the transactions were concluded. Another aspect of this topic has been hidden for the society, namely, the properties for which higher taxes and fees are required due to the deviations between the market value and the taxable value. No comments have been made about how residents of a number of Bulgarian areas pay tax on a higher basis because of the "management fear" of reforming the existing system.

Since 2003, at different rates in our country, a process of financial decentralization has taken place, with the ultimate goal of local authorities having sufficient incomes and financial autonomy to spend them in line with the needs of the local population. This

\footnotetext{
*Correspondence to: PhD student Daniela Ushatova, Department of Regional Development, Trakia University,Stara Zagora, Bulgaria, e-mail: d_ushatova@abv.bg
}

concerns the practical realization of Art. 9 of the European Charter of Local SelfGovernment, that is, local self-government bodies have the right within the national economic policy to have sufficient own resources to freely dispose of in the exercise of their powers, and the financial mechanisms providing the funds are sufficiently diverse and a subject to development and to allow municipalities to follow, as far as practicable, the natural increase in the cost of exercising their powers. (1) In this context, Richard Bird notes that: "Local authorities should not only have access to those sources of revenue they can best use, such as real estate tax and public utility service charges, but also need to be encouraged to use those revenue sources without excessive oversight by the central government". (2) Real estate taxes have always been one of the most important sources of revenue in the historical development of tax systems. Real estate can hardly be hidden and at the same time easy to assess and for this reason it has become one of the most sustainable models for administering tax revenues by emperors, kings, and later by municipal governments. (3) 
For Bulgarian municipalities, without exception, the real estate taxes are a traditional and main source of income. Following the changes to the Constitution of the Republic of Bulgaria (4) in 2007, municipalities were given the right to determine the value of taxes under conditions, within the limits established by law. Although our country is among the countries with a low share of property taxes, both as a percentage of GDP and as a percentage of national tax revenues, as a result of the decentralization of the powers of the municipalities to administer them (since 2006) of tax rates (since 2008), the proceeds of real estate tax has been increasing steadily.

The rates of revenue growth of this tax over the years are different, with the most significant increases being recorded following a change in the base - real estate tax assessments. The decisions to change the tax assessment are entirely in the "hands of the central government", as the Methodology for its calculation is defined in the Local Taxes and Fees Act (5). Apart from being the main tax revenue source of municipalities, tax assessment is a traditional instrument for fair and objective:

- Determination of the basis of inheritance tax and property tax (municipal own revenues). By 2021, incl. tax assessments can also be used as a basis for determining a municipal waste tax;

- Comparison / determination of other taxes and fees by other state bodies. According to Art. 3, para. 2 of Appendix 2 to the Local Taxes Tax Act, the tax assessment also serves to determine the state and notary fees in the proceedings under the Civil Procedure Code and in other cases provided for by the law. For example, to determine the amount of the costs of claims and the initial price at the first public sale under the Civil Procedure Code and to determine the public receivables to be secured and the valuations in the public sale under the Tax Insurance Procedure Code. The tax assessment is used by the notaries to determine the fees due for dispensing deals with immovable property;

- Protecting the public interest in disposing transactions under the State Property Act and the Municipal Property Act.

For these reasons, the tax assessment has a direct relation to the receipts not only from the municipal budgets, but also from the national budget.
USHATOVA D.

Unlike a tax assessment that has a clearly defined purpose and a clear formula to determine (depending on a number of characteristics of the property concerned), there is no real measure of market value. Regarding the verification of transactions in real rights, an attempt was made in the Notaries and Notary Act (6) to establish some general statements. There is also a specific definition of the market price - "§ 2. The market price shall be determined by the price that could be obtained in normal market relations, taking into account the nature of the object and all factors affecting the selling price, respectively when renting. The assessment shall be determined by the order of Art. 33 of the Law on Local Taxes and Fees. "The reference to the cited provision of the Act refers to the valuation in $\mathrm{BGN}$ at the moment of inheritance, the respective value being determined: for the immovable property on the territory of the country is done by a tax assessment; for undertakings or shareholdings in commercial companies or cooperatives - at market value and, where the determination requires significant costs or difficulties, on accounting data without differentiating between immovable property included in their capital and assets; and for immovable property in the territory of another state - by a tax value specified in a document issued for taxation purposes by a competent authority of the respective country, accompanied by a correct translation into Bulgarian made by a sworn translator.

Due to legislative deficiencies and the "frozen" methodology for determining tax assessment, the present study aims to show the respective imperfections in determining tax assessments in different settlements and in different zones and their deviation from the notional market prices. The results of the experimental comparison of the prices of 1 sq. M., Announced in a popular real estate site with the corresponding value of the tax assessment for $1 \mathrm{sq}$. M. for properties with the same basic characteristics from selected municipal centers from different planning regions.

The dogmatic method has been used to derive a set of ways, means, techniques, and ways to formulate the legally valid value of the tax assessment. To determine the imbalances a comparative analysis of the results obtained on the basis of a comparison of the selected properties (with approximately the same characteristics) with similar ones on the real 
estate market, as well as those with which transactions have already been made.

The basic data is based on current legislation (Local Taxes and Fees Act), publicly available information on real estate prices on a leading site - imot.bg, NSI and Eurostat. The information on real estate tax revenues is derived from the published annual budget execution reports on the websites of the surveyed municipalities.

On the basis of the results of the survey, it is possible to define main directions for improving the formula for determining the tax assessment of the individual types of real estate and / or to determine the expected growth / deficit that is formed in the respective municipal budgets as a result of the established discrepancies between tax assessments and real property prices.

\section{MATERIAL AND METHODS}

1. Models for determining the tax assessment of a property and the market valuation of the respective property

In the context of the work of the founder of the spatial economy, von Thünen, "draws the attention of economic thought to the role of the city in the economy. With the development of technologies and the improvement of social structures, the importance of natural factors for the economy is decreasing, and that of the anthropogens, ie. of those connected with people and their activity - is increasing. The city, as an organized cluster of people, subordinates itself to the geographical environment in its economic context." (7)

Because real estate is permanently positioned in space, its owners and occupants are actually part of the local community. In this capacity, they benefit from most public services and, as taxpayers, contribute to increasing their quantity, quality and scope. (8) With an active property market with rising values, it can be argued that local communities can share the corresponding increases in their value as a result of economic, demographic and urban growth.

Real estate tax is levied on the land plots, buildings and individual buildings situated on the territory of the country in buildings within the building boundaries of the settlements and settlement formations, as well as the landed estates outside them. The tax assessment of the immovable property shall be determined according to the tax assessment norms of the immovable property approved by Annex 2 of the Local Taxes Act, depending on the type of the property, the location, the area, the construction and the waiter, and shall be communicated to the taxable persons, as follows:

- of the citizens - shall be determined by an employee of the municipal administration according to the norms according to appendix No 2 to the Act, depending on the type of the property, the location, the area and the construction and shall be reported to the tax obliged people.

- of the enterprises - is higher between the book value and the tax assessment according to Appendix 2, and for the residential properties their tax assessment according to Appendix 2 and in case of lack of accounting data experts may also be used to review the issue.

- the real estate on which the right of use of an enterprise is constituted - is their book value on the owner's balance sheet or the tax assessment according to Appendix 2, and for the residential properties - the tax assessment according to Appendix 2, in the absence of accounting data to use and experts review.

- The properties on state or municipal landed property on which buildings of enterprises are built - shall be determined according to the norms of Annex 2 of the Act.

- Irrespective of the type of property, tax assessment is a major factor in determining the tax liability of tax obliged people.

According to the Constitution of the Republic of Bulgaria, citizens are obliged to pay taxes and fees, established by law, according to their income and property.

In order to determine the actual valuation of the property in question, different models are used to determine the monetary value against which the same property can be purchased (with identical characteristics - technical parameters, age, location, construction, etc.). The most commonly used approaches to determining the real value of property are: expert judgment (expert based on standardized criteria), market price (acceptable benchmark for the actual value of property of a similar type, eg. on the same territory, neighborhood, area etc.), the adjusted market price (allows to avoid inaccuracies in the use of the market price by adjusting it to the value of the relevant improvements) or the cost / price the seller has received (in real dealings).

An exception to these commonly accepted approaches exists with regard to municipal 
dwellings for which a local regulation has been adopted in some municipalities with a clear methodology for determining the sale price of residential and residential buildings in the tenants' premises occupied by them. ${ }^{1}$

"The price is a monetary amount requested, offered or paid for a particular asset. It is a historical fact whether declared or kept secret and refers to a certain moment and place. Depending on the financial capabilities, motives or financial interests of a particular buyer and seller, the price paid may not correspond to the value attributed to the object by other people." (9) Given these conventions, for the purposes of the survey, only data on" requested sums of money "For certain types of properties. These prices are derived from the published statistics on one of the main Internet portals for real estate trading - imot.bg as of the end of 2016, 2017 and 2018 for the respective types, by zones and examined municipal centers. There are no smaller municipalities because of the lack of enough or any of the listed properties. At present, there is no public information about the material interest of real estate transactions and / or mortgages registered in the Registry Agency that are significantly closer to the real market prices.

For the purposes of the report, it was chosen to study only the differences between the tax assessment and the market price of $1 \mathrm{sq}$. M. for similar properties in selected settlements from different planning regions. The declared selling prices of these properties and the average price of residential properties, according to NSI data, are compared with the provisionally calculated value of the tax assessment for each type of property under investigation obtained under the rules of the Local Taxes and Fees Act.

\section{Expert assessment}

As a whole, the study of regulatory changes and regulations regarding the tax assessment norms reveals the following problems:

2.1. Essentially unchanged formula for determining tax assessments - since the

\footnotetext{
${ }^{1}$ The Ordinance on Prices for Real Estate Transactions of the Municipality of Sofia was adopted in 2008 by the Sofia Municipal Council. It has been found that residential buildings and dwellings in them are estimated per square meter of gross (gross) area, using the base value of 1 square meter, the type and structure of the building, the coefficients for the area of the settlement, the subarea the settlement and other correction factors.
}

USHATOVA D.

adoption of the Tax Assessment Standards, according to Appendix 2 of the Local Taxes Act in 1997 to date. The formula for determining the tax assessment of real estate in levs contains one basic component - a basic tax value of 1 sq.m. in BGN, determined by the type and quadrature of the building and additional correction coefficients, as follows:

- the basic tax value of 1 sq.m. in levs differentiates according to construction, type - apartment, house or non-residential property from 3.7 to $18.70 \mathrm{BGN} /$ sq.m .;

- $\mathrm{Km}$ - Positioning factor (last changed since 2008, when most coefficients were increased by 2.13 times to 3.28 times depending on the categories of settlements). Thus, the properties are differentiated according to the category of area, zone, type of residential property (ranging from 2.2 to 93.6) and favorable and unfavorable layout of non-residential properties (varies from 1.1 to 23.4);

- $\mathrm{Ki}$ - infrastructure factor - differentiated for water supply, electricity, district heating, telephony and streets (within the range of 0,08 to $+0,06$ );

- $\mathrm{Kx}$ - coefficient for individual characteristics

- location at the height of objects (within the range of -0.10 to +0.10 );

- Physical state of the site (within the range of -0.10 to -0.60$)$;

- $\mathrm{Kv}$ - coefficient of height when the height of the floor is more than four meters;

- Co - coefficient of deterioration from the completion of the building up to the time of the assessment by type of construction (in the range of 0.5 to 1 ), with a recalculation of this coefficient applied over the years at 10 and 5 years.

2.2. Unchanged over the last 22 years levels of is the basic component for the determination of the tax assessment - basic tax value of 1 sq.m.

Fully preserved at the levels since 1997 are the basic tax value in BGN per square meter of real estates by types of constructions, construction (apartments, houses and nonresidential buildings) - between BGN 3.7 per sq.m. and BGN 18.7 per sq $\mathrm{m}$. and the land 0,80 BGN / sq.m. For this period, only the basic tax rates of the agricultural lands have increased by $50 \%$ from 2009 - depending on the category of agricultural land this value is from BGN 0.003 to BGN 0.338 per square meter. 
2.3. Deviations between actual market prices and tax assessment.

There are a number of examples on the ground both of lowering the tax assessment against the real one, ie. those with a significantly higher value of tax assessments than market prices. A typical example of the first kind of deviations are the properties in smaller, lower-functional settlements, where their tax assessments are traditionally under-deductible and even fall into the "non-taxable" category (with a tax assessment below BGN 1,680). Municipalities classified as resorts but practically lacking tourism and / or investment activity also say that property tax assessments are significantly higher than market prices, which is an additional barrier to attracting investors ( according to the provisions of the PPL, the municipality cannot realize transactions at prices lower than the tax assessment). Unlike the examples above, there is the other type of deviation in the bigger and more economically active municipalities - tax assessments are lagging behind real market prices.

Overall, at national level, a lower tax assessment of agricultural land is reported, from which all municipalities "lose income" and from a tax on property forfeiture.

Until 2006 inclusive, according to the provision of the repealed Art. 5 of the LTVT, the tax assessment could be changed when the index of market values of real estates (according to NSI data) increased or decreased by more than 20 per cent cumulatively for the period since their last change. In earlier versions of this provision, until 2005, even the period within which its amount could be amended, namely - but no later than 30 November of the previous year.

In practice, tax assessments have been amended over the years mainly by an increase in the location coefficients, and only on the basis of these abrogated norms.

2.4. The location factor has the most significant impact on the tax assessment rate. The location factor is determined according to the Unified Classifier of the Territorial and Territorial Units (EKATTE) (10), with the exception of Varna, Bourgas, Stara Zagora, Plovdiv and the areas in the I (first) category divided by vague criteria into two groups. In this category of settlements are included both resort municipalities and villages, such as Sveti Vlas and Kranevo, as well as district centers.
In fact, this category also has the highest coefficient increases - more than 3 times.

The municipalities, districts, mayoralties and areas are categorized by criteria and indicators determined by the Council of Ministers, but the categorization itself is done by an order of the Minister of Regional Development and Public Works and is promulgated in the "State Newspaper". However, it is not clear how municipalities and the property market are influenced by this categorization of settlements. Also, taxpayers could hardly foresee the financial consequences of a possible change in the categorization of settlements, as this order is not subject to mandatory public consultation under the Law on Legal Acts.

2.5. In the tax assessment formula, we use coefficients for "undetectable" and other important property features are missing.

In determining the tax assessment, municipalities do not have a real tool to correctly report (beyond the declared data) whether the property has undergone an internal overhaul over 20 years. Irrespective of the market value of the property, there are also the coefficients for telephony due to faulty importance for these infrastructures (water supply, sewerage, electrification, street network) for agricultural properties due to incompatibility with the purpose and the category of the land. On the other hand, other circumstances, such as accessibility to mass urban transport, should be taken into account in the tax assessment; to public services educational and healthcare facilities, access to parks, green areas, etc.

When defining the characteristics of the surveyed properties, it is precisely for the reasons set out that such are not pledged.

\section{Empirical study of imbalances between tax assessments and market prices of real estate.}

For the purposes of scientific research, the following model of analysis was applied:

- Several types of taxable properties have been identified: an apartment, an old brick with a total area of 65 sq.m., 30 years, a two-story house with a total built-up area of 100 sq.m. and an uninhabited yard of 450 sq.m. and plot on the periphery of the urbanized urban area between 1000 and 2000 sq.m.

- Various municipalities identified on the territory of which are located on the https://www.imot.bg real estate site in the 
USHATOVA D.

above mentioned characteristics have been identified and the respective selling price is set at 1 sq.m. for the same period at the end of the previous 3 years.

- The tax assessments of the properties selected above have been calculated according to the tax assessment rates set in the LTRO and an average value of 1 sq.m.
- For the selected settlements the average price was determined by NSI data, based on the published values up to 2014, updated according to the published indexes for the period $2015-2018$.

the data used in the research - for value in BGN per 1 sq.m. for the studied types of properties and settlements are presented in Table 1.

Table 1. Value data in BGN per 1 sq.m. for the studied types of properties

\begin{tabular}{|c|c|c|c|c|c|c|c|c|c|c|}
\hline \multirow{2}{*}{\multicolumn{2}{|c|}{$\begin{array}{l} \\
\text { Researched } \\
\text { properties }\end{array}$}} & \multicolumn{3}{|c|}{$\begin{array}{l}\text { Average market } \\
\text { prices of real estate } \\
\text { in BGN per } 1 \text { sq.m. } \\
\text { (imot.bg) }\end{array}$} & \multicolumn{3}{|c|}{$\begin{array}{l}\text { Tax assessment in } \\
\text { BGN per } 1 \text { sq.m. }\end{array}$} & \multirow{2}{*}{\begin{tabular}{|l|} 
Average \\
market \\
price in \\
BGN \\
per 1 \\
sq.m. \\
\end{tabular}} & \multirow{2}{*}{\begin{tabular}{|l|} 
Average \\
tax \\
assessment \\
in BGN \\
per 1 \\
sq.m. \\
\end{tabular}} & \multirow{2}{*}{$\begin{array}{l}\text { Average } \\
\text { market } \\
\text { price } \\
\text { per 1 } \\
\text { sq.m., } \\
\text { NSI } \\
\end{array}$} \\
\hline & & A & $\mathrm{H}$ & $\mathrm{P}$ & $\mathrm{A}$ & $\mathrm{H}$ & $\mathrm{P}$ & & & \\
\hline \multirow{3}{*}{ Sofia } & 2016 & 2038 & 3605 & 274 & 1582 & 422 & 24 & 1972 & 676 & \\
\hline & 2017 & 2322 & 3605 & 291 & 1573 & 420 & 24 & 2073 & 672 & 1932 \\
\hline & 2018 & 2322 & 6171 & 293 & 1564 & 417 & 24 & 2929 & 669 & 2044 \\
\hline \multirow{3}{*}{ Sliven } & 2016 & 847 & 542 & 29 & 517 & 170 & 10 & 473 & 232 & 616 \\
\hline & 2017 & 773 & 737 & 22 & 514 & 169 & 10 & 510 & 231 & 649 \\
\hline & 2018 & 773 & 424 & 20 & 512 & 168 & 10 & 406 & 230 & 670 \\
\hline \multirow{3}{*}{$\begin{array}{l}\text { Stara } \\
\text { Zagora }\end{array}$} & 2016 & 1054 & 1076 & 51 & 1038 & 351 & 20 & 727 & 470 & 961 \\
\hline & 2017 & 1109 & 904 & 51 & 1032 & 349 & 20 & 688 & 467 & 1012 \\
\hline & 2018 & 1244 & 518 & 53 & 1026 & 348 & 20 & 605 & 465 & 1045 \\
\hline \multirow{3}{*}{ Varna } & 2016 & 1657 & 728 & 156 & 1460 & 422 & 24 & 847 & 635 & 1535 \\
\hline & 2017 & 1614 & 728 & 156 & 1452 & 420 & 24 & 833 & 632 & 1659 \\
\hline & 2018 & 1629 & 728 & 156 & 1444 & 417 & 24 & 838 & 628 & 1749 \\
\hline \multirow{3}{*}{ Vratsa } & 2016 & 775 & 397 & 29 & 517 & 170 & 10 & 400 & 232 & 542 \\
\hline & 2017 & 816 & 190 & 31 & 514 & 169 & 10 & 346 & 231 & 592 \\
\hline & 2018 & 884 & 190 & 39 & 512 & 168 & 10 & 371 & 230 & 624 \\
\hline \multirow{3}{*}{ Gabrovo } & 2016 & 706 & 383 & 12 & 517 & 170 & 10 & 367 & 232 & 521 \\
\hline & 2017 & 706 & 346 & 12 & 514 & 169 & 10 & 355 & 231 & 539 \\
\hline & 2018 & 751 & \begin{tabular}{|l}
563 \\
\end{tabular} & 16 & 512 & 168 & 10 & 443 & 230 & 569 \\
\hline$A$ & \multicolumn{10}{|c|}{$\begin{array}{l}\text { apartment, old col } \\
\text { sq.m., Center }\end{array}$} \\
\hline$H$ & \multirow{2}{*}{\multicolumn{10}{|c|}{$\begin{array}{l}\text { two-storey house with total living area of } 100 \text { sq.m. and a yard of } 450 \text { square meters } \\
\text { plot on the periphery of the urbanized urban area between } 1000 \text { and } 2000 \text { sq.m. }\end{array}$}} \\
\hline$P$ & & & & & & & & & & \\
\hline
\end{tabular}

Overall, at market prices of 1 sq.m. the following general trend trends for the 3-year study can be deduced:

With regard to market prices:

- Prices in BGN per 1 sq.m. in the case of apartments, they increase or keep the level of a previous year anywhere.

- At house prices, growth is reported only in Sofia, and for Varna there is a "freezing". For all the others, a decrease in prices of this type of property is reported, which is more than $50 \%$ for Vratsa and Stara Zagora.
- Regarding the parcels surveyed, with the exception of Sliven, where the prices per sq. M. Decrease in Varna, where they remain constant, in all other settlements there is an increase, albeit minimal.

With regard to the amount of tax assessments: - A very minimal decrease for the period is recorded for the construction works apartments and houses, which is due to the deterioration factor, which on a yearly basis leads to a decrease of $0.0057 \%$.

- For parcels, tax assessments remain constant. 
The price data presented in BGN per 1 sq.m. for the types of properties are averaged as a value in order to achieve comparability with
USHATOVA D.

NSI data, which are common, not by type of property. The results are presented in Table 2.

Table 2. Deviation of the results for tax assessment compared to the market prices and NSI data.

\begin{tabular}{|c|c|c|c|c|c|}
\hline \multirow{2}{*}{\multicolumn{2}{|c|}{$\begin{array}{l}\text { Researched } \\
\text { properties }\end{array}$}} & \multicolumn{3}{|c|}{$\begin{array}{l}\text { Share of the tax assessment at the } \\
\text { average market prices of real estate } \\
\text { in BGN per } 1 \text { sq.m. (Imot.bg) }\end{array}$} & \multirow{3}{*}{$\begin{array}{l}\text { Share of the average tax } \\
\text { assessment (A and } \mathrm{H}) \text { at } \\
\text { the average market } \\
\text { prices of real estate in } \\
\text { BGN per } 1 \text { sq.m. (NSI) }\end{array}$} \\
\hline & & A & $\mathbf{H}$ & $\mathbf{P}$ & \\
\hline \multirow[t]{3}{*}{ Sofia } & 2016 & $78 \%$ & $12 \%$ & $9 \%$ & \\
\hline & 2017 & $68 \%$ & $12 \%$ & $8 \%$ & $52 \%$ \\
\hline & 2018 & $67 \%$ & $7 \%$ & $8 \%$ & $48 \%$ \\
\hline \multirow[t]{3}{*}{ Sliven } & 2016 & $61 \%$ & $31 \%$ & $34 \%$ & $56 \%$ \\
\hline & 2017 & $66 \%$ & $23 \%$ & $45 \%$ & $53 \%$ \\
\hline & 2018 & $66 \%$ & $40 \%$ & $50 \%$ & $51 \%$ \\
\hline \multirow{3}{*}{$\begin{array}{l}\text { Stara } \\
\text { Zagora }\end{array}$} & 2016 & $98 \%$ & $33 \%$ & $39 \%$ & $72 \%$ \\
\hline & 2017 & $93 \%$ & $39 \%$ & $39 \%$ & $68 \%$ \\
\hline & 2018 & $82 \%$ & $67 \%$ & $38 \%$ & $66 \%$ \\
\hline \multirow[t]{3}{*}{ Varna } & 2016 & $88 \%$ & $58 \%$ & $15 \%$ & $61 \%$ \\
\hline & 2017 & $90 \%$ & $58 \%$ & $15 \%$ & $56 \%$ \\
\hline & 2018 & $89 \%$ & $57 \%$ & $15 \%$ & $53 \%$ \\
\hline \multirow[t]{3}{*}{ Vratsa } & 2016 & $67 \%$ & $43 \%$ & $34 \%$ & $63 \%$ \\
\hline & 2017 & $63 \%$ & $89 \%$ & $32 \%$ & $58 \%$ \\
\hline & 2018 & $58 \%$ & $88 \%$ & $26 \%$ & $54 \%$ \\
\hline \multirow[t]{3}{*}{ Gabrovo } & 2016 & $73 \%$ & $44 \%$ & $83 \%$ & $66 \%$ \\
\hline & 2017 & $73 \%$ & $49 \%$ & $83 \%$ & $63 \%$ \\
\hline & 2018 & $68 \%$ & $30 \%$ & $62 \%$ & $60 \%$ \\
\hline \multicolumn{6}{|c|}{ 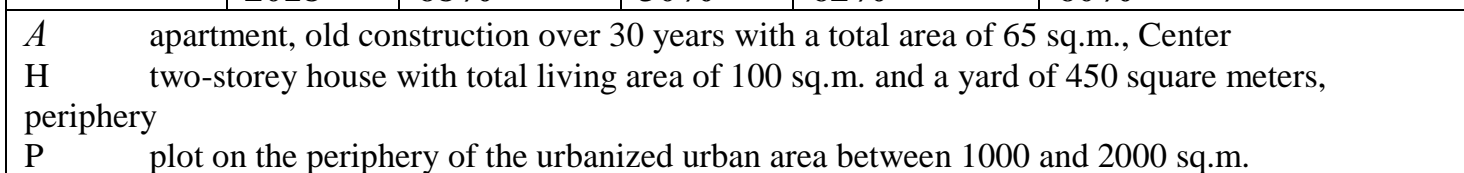 } \\
\hline
\end{tabular}

As can be seen from the results in Table 2, the deviation between the tax assessment and the market price differs depending on the type of property. With the exception of Varna, which is also a resort municipality, for all other studied areas there is a clear tendency to decrease the share of the tax assessment in the market value of the investigated apartments. In terms of the surveyed results for the houses - for Vratsa, Sliven and Stara Zagora, low tax assessments are beginning to approach "timidly" to market prices. This is largely due to the downward trend in the prices of such properties.

In general, the surveyed municipalities report a fall in tax assessments from market prices for houses and plots.

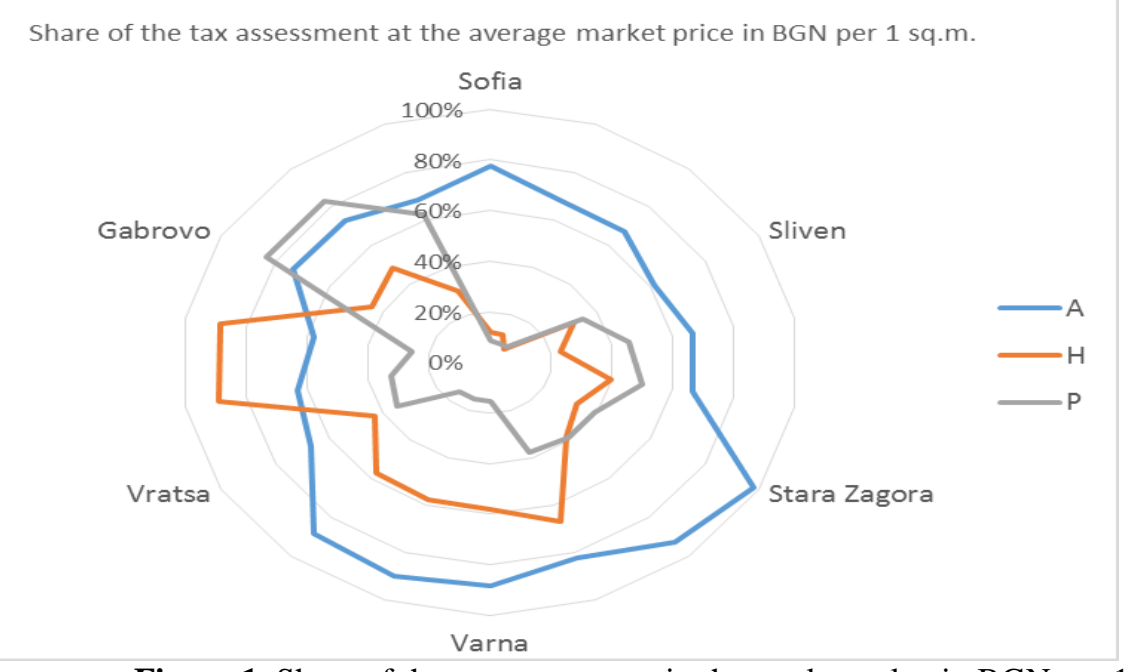

Figure 1. Share of the tax assessment in the market value in BGN per 1 sq.m. 


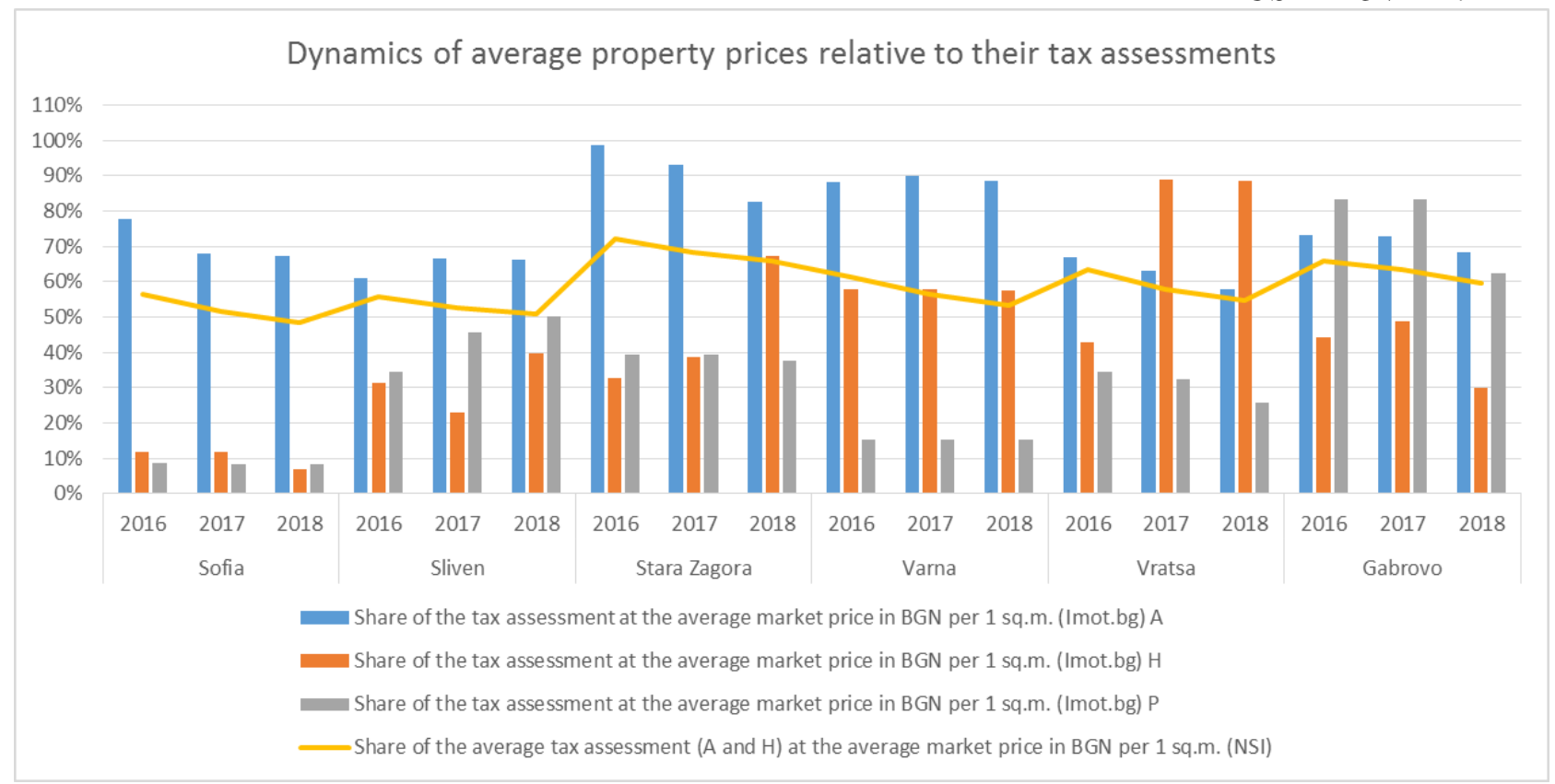

Figure 2. Share of the tax assessment in the market value in BGN per 1 sq.m., 2018

As can be seen from the graphs, for 2018, the smallest deviation in municipalities is observed at the prices of the apartments, unlike those of the houses and especially the parcels.

\section{Discussion of results and possible solutions}

The unchanged mechanism for determining the tax assessment of real estate without the inclusion of a dynamic indicator that takes into account changes in its prices on the real market creates conditions for paying lower taxes compared to the value of the property owned. The lack of an official and publicly available source of real estate prices detracts from state and municipal budgets, and hence from citizens, in terms of their right to receive more and better public services than tax revenues collected.
The correction factors applied in the formula for determining the tax assessment of real estate, particularly with regard to location, have a significant effect on the amount of the tax assessment. Correction coefficients do not have a real estate market where the price depends on supply and demand, as determined by other factors.

By type of property there is a different degree of deviation of the tax assessment from the announced market prices. The largest imbalances in the surveyed municipalities are reported in the houses and plots. For apartments - imbalances are smaller. Average values are presented in Figure 3.

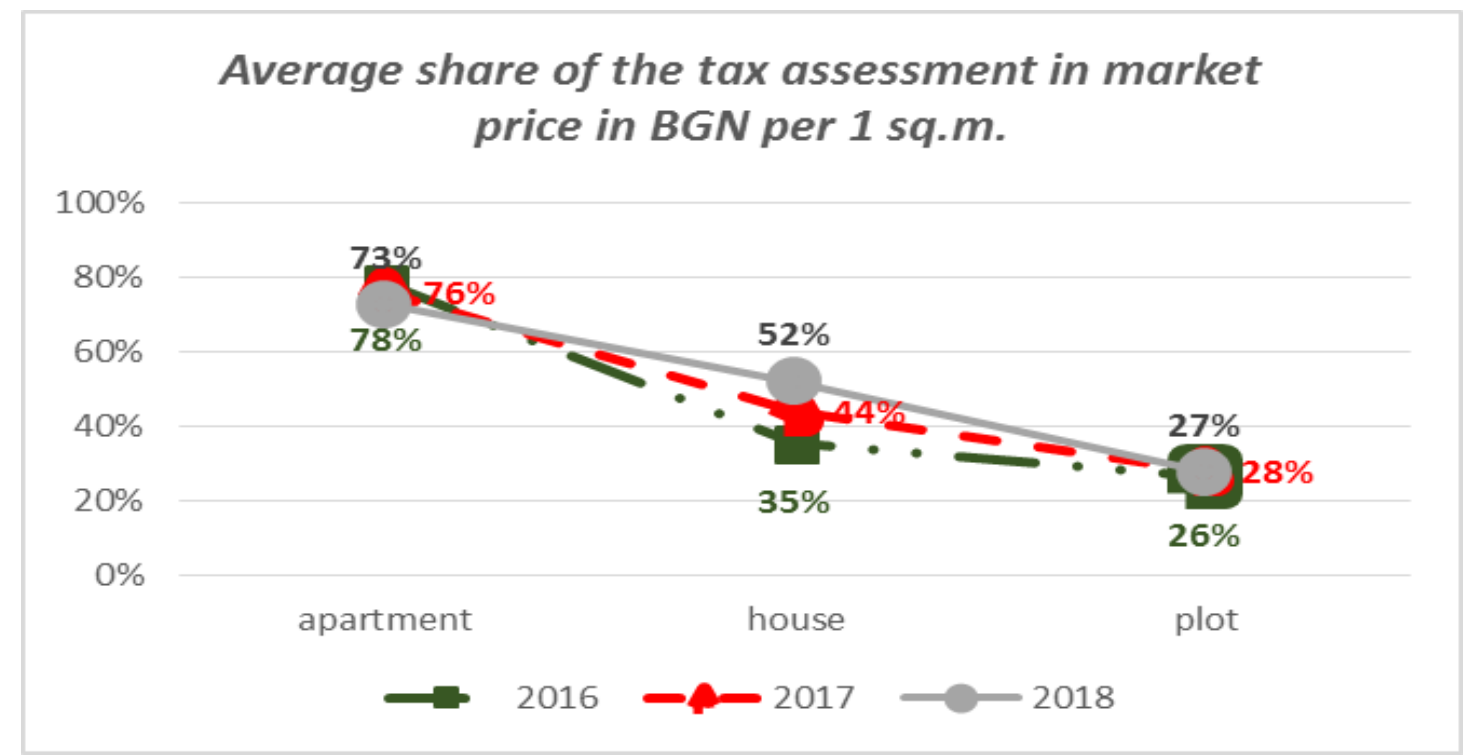

Figure 3. Average share of the tax assessment in market prices of real estate in BGN per 1 sq.m. 
First of all, in order to find a solution for the equal assessment of the tax assessment of a property it is necessary to determine what basis for determining the market price will be used expert assessment or data from an official register of a state body or NSI. In the first option it is impossible and costly to determine this price by a licensed expert. In the second option, it is relatively easy to get information about the material interest registered in the notarial acts in the real estate transactions, but similar data is available only for the settlements where there are enough transactions with different property characteristics. In the third option - NSI is about to realize the national census of the population and the housing stock and on this basis it is possible to obtain reliable statistical information, incl. and to specify the types of taxable property and structures.

An easily applicable approach to determining the tax assessment could be the regulatory arrangement that its amount is determined as a percentage of the market price of properties with similar characteristics. In this case, it is clearly defined which authority monitors and publishes data on the average market price.

To present the results using this approach, it is assumed that $80 \%$ is the optimal option that would be relatively easy to accept by property owners. Experimental calculations of changes in the amount of real estate tax revenues were made, taking into account the fact that there is no basic official information on the structure of the taxable property - residential and nonresidential properties, respectively the revenues from these properties by municipalities. It is assumed that in order to calculate the expected financial impact of such a decision, only the proportion of houses in the total number of residential properties in the area concerned is used, according to the published results of the National Population and Housing Census in 2011 (publicly disclosed only results per district, with houses accounting for more than 70 percent of residential properties). Real estate tax revenue data is used in the cash performance reports of the budget, bearing in mind that there is no analytical presentation in the income statement by type of property, and that cash receipts are also included in the receipts collected from 2018, which hasn't been done in past years. It is assumed that the reported amounts are for residential property only.

On this basis, experimental results are presented for the surveyed municipalities presented in Table 3.

Table 3. Experimental assessment of the option to approximate tax assessments to market ones.

\begin{tabular}{|c|c|c|c|c|c|c|c|}
\hline Municipalities & $\begin{array}{l}\text { Revenue } \\
\text { from } \\
\text { property } \\
\text { tax in } \\
\text { BGN, } \\
2018 \\
\end{array}$ & $\begin{array}{l}\text { Tax } \\
\text { assessment } \\
\text { of } 1 \text { sq.m. }\end{array}$ & $\begin{array}{l}\text { Market } \\
\text { prices } \\
\text { of real } \\
\text { estate } \\
\text { per } 1 \\
\text { sq.m. } \\
\end{array}$ & $\begin{array}{l}\text { Correction } \\
\text { coefficient } \\
\text { to reach the } \\
\text { tax } \\
\text { assessment } \\
\text { to } 80 \% \text { of } \\
\text { the market } \\
\text { price }\end{array}$ & $\begin{array}{l}\text { Share of } \\
\text { houses in total } \\
\text { housing, data } \\
\text { National } \\
\text { Census 2011, } \\
\text { NSI }\end{array}$ & $\begin{array}{l}\text { Expected } \\
\text { change in } \\
\text { revenue, } \\
\text { ceteris } \\
\text { paribus }\end{array}$ & $\begin{array}{l}\text { Expected } \\
\text { change in } \\
\text { revenue\%, } \\
\text { ceteris } \\
\text { paribus }\end{array}$ \\
\hline Sofia & 106291739 & 417 & 6171 & 11,8 & $70 \%$ & 800350937 & $753 \%$ \\
\hline Sliven & 5731202 & 168 & 424 & 2,0 & $88 \%$ & 5142411 & $90 \%$ \\
\hline Stara Zagora & 6345137 & 348 & 518 & 1,2 & $91 \%$ & 1111886 & $18 \%$ \\
\hline Varna & 32152245 & 417 & 728 & 1,4 & $73 \%$ & 9231036 & $29 \%$ \\
\hline Vratsa & 1480718 & 168 & 190 & 0,9 & $78 \%$ & -110865 & $-7 \%$ \\
\hline Gabrovo & 1713930 & 230 & 443 & 1,5 & $90 \%$ & 836410 & $49 \%$ \\
\hline
\end{tabular}

It is noteworthy that Sofia would have "favored" the most from the application of such an approach, unlike Vratsa, where there would be a drop in real estate tax revenues. Overall, the approach with the application of only a unified percentage to market prices would lead to larger distortions by municipalities.
This disadvantage may be overcome by defining a new power for municipal councils to set additional correction coefficients (to reduce or increase the value thus obtained) in legally defined ranges. This will enable each municipality to reduce imbalances between tax assessments and market prices of properties. Such a solution in the current system of determining the amount of the real estate tax 
within the range of 0.1 to 4.5 per thousand is impossible.

\section{REFERENCES}

1. European Charter for Local SelfGovernment (Strasbourg, 15.X.1985), ratified by law, by the 37th National Assembly on 17.03.1995, SG, No. 28 of 28.03.1995

2. Bird, R. M. (1993). Threading the fiscal labyrinth: Some issues in fiscal decentralization. National Tax Journal 46(2):p.211.

3. Robert, E. \& Seligman, A. (1921). Essays in Taxation. New York - London: Macmillian.

4. Constitution of the Republic of Bulgaria, SG. No. 56 of 13.07 .1991

5. Local Taxes and Fees Act, SG. No. 117 of 10 December 1997

6. Notaries and Notary Act, SG. No. 104 of 6 December 1996
7. Collective, Collection of studies "Economics and Management of Real Estate", University Publishing House "Holding", University of National and World Economy, Sofia, 2011 (p.12)

8. Grover R., Walacik M., 2019, Property Valuation and Taxation for Fiscal Sustainability - Lessons for Poland, Real Estate Management and Valuation, vol. 27, no. 1, (p. 36).

9. Collective, Collection of studies "Economics and Management of Real Estate", University Publishing House "Holding", University of National and World Economy, Sofia, 2011 (p.51)

10.Unified classifier of administrativeterritorial and territorial units (EKATTE), Publishing Solutions with № 565 of Ministers Accountancy 1999 (SG. No.73 of 1999) 